Nodes of Contemporary Finnish Literature är en ambitiös och uppslagsrik antologi. De sammangyttringar som valts för djupare studium placeras både i sina litterära och i nyskapande teoretiska sammanhang. Sammantagna utgör artiklarna en stimulerande kartritning över nuläget $\mathrm{i}$ finländsk skönlitteratur. På bästa sätt genererar antologin läslust och inte minst lust att följa i de teoretiska spår som här presenteras.

\title{
Skribent
}

Mia Österlund, docent, universitetslärare, Åbo Akademi, litteraturvetenskap (mosterlu[at]abo.fi)

\section{Suomalainen tekijäpeli ranskalaisin säännöin}

Kaisa Kurikka: Algot Untola ja kirjoittava kone. Turku: Eetos, 20 I 2. 349 s.

Kaisa Kurikan väitöskirja alkaa luettelolla Algoth Tietäväiseksi ristityn miehen monista myöhemmistä nimistä. Luettelo lähtee liikkeelle ensimmäisestä itse otetusta nimestä Algot Untola, joka tutkimuksessa muodostaa sateenvarjon tekijyyden kokonaisuudelle. Yhteensä nimiä oli yli neljäkymmentä. Parhaiten näistä kirjailijana tunnetaan Maiju Lassila, mutta myös Irmari Rantamalan nimissä julkaistiin viisi romaania ja J.I. Vatasen nimissä yksi. Muut nimet esiintyivät julkaisemattomien käsikirjoitusten nimiölehdillä, lehtikirjoituksissa, kirjeiden allekirjoituksissa.

Kurikan väitöstutkimuksessa suhteutetaan eri tekijänimiä toisiinsa, tehdään erontekoja ja samastuksia, "kartografiaa tekijästä käsitteellisenä henkilönä" (s. 35). Käytännössä muotoilu tarkoittaa sitä, että sekä Untolan tekijyyksien kautta että teosten sisäisten kirjailijahahmojen kautta eritellään tekijyyden eri puolia, siihen kohdistuvia odotuksia ja erilaisia tekijyyden mahdollisuuksia.

Väitöskirja alkaa provokatorisesti Untolan kuolemasta vuonna 1918 epämääräisissä olosuhteissa. Untola oli syytettynä kirjoittamistaan vääristä sanoista, poliittisesta vääräoppisuudesta. Untola, elävä ruumis eri tekijänimien takana, kuoli, vaikka allekirjoituksena tuomion tuoneessa tekstissä oli Irmari Rantamala. Aloitus kyseenalaistaa tekijän 
kuolemaan liittyviä yleistyksiä ja tekijänimien irrallisuutta todellisesta henkilöstä ja tuo fyysistä ruumista takaisin tekijyyden analyysiin. Se saa odottamaan, että fyysinen ihminen kirjoituksensa takana otettaisiin vahvasti huomioon tutkimuksessa. Mutta vaikka julkaistun tuotannon lisäksi analysoidaan arkistomateriaalia, kirjeitä ja julkaisemattomia käsikirjoituksia, ruumiillisen tekijän sijasta huomio kohdistetaan "eettisesteettiseen tekijyyteen" sen abstraktissa muodossa. Kurikan mukaan Untolan elämä tulee näkyviin kirjoituksena, ei kerrottuna elämäntarinana.

Kaisa Kurikan väitöskirja analysoi paitsi Untolan tekijyyskoostetta, myös kirjoittaa suomeksi Gilles Deleuzen ja Félix Guattarin ajattelua hyödyntävää kirjallisuudentutkimusta. Deleuzelaiseksi kirjallisuudentutkimukseksi nimettyä tutkimusotetta ei Suomessa ole juuri harjoitettu, ja Kurikan väitöskirjasta aiheesta kiinnostunut saa kattavan lähdemateriaalin. Tämän lisäksi yleisesti tekijyystutkimuksesta kiinnostuneelle kirja tarjoaa rehevän lähdeaineiston, josta lähteä piirtämään oman tutkimuksensa ääriviivoja.

Deleuze ja Guattari ovat tyypillisiä filosofisesti orientoituneita ranskalaistutkijoita siinä, että heidän ajatuksensa on puettu vaativaan muotoon. Kurikan tutkimus esittelee heidän käyttämiään käsitteitä: se pohtii re- ja deterritorialisaatiota, sovittaa deleuzelaista kertosäkeen ideaa tekijänimen toistoon ja etsii Untolan käytännöistä, eleistä, pakoviivoja uusiin, vielä valloittamattomiin maastoihin. Lisäksi Kurikka avaa uusia teoreettisia näkökulmia Deleuzen ja Guattarin nimenomaisen pyynnön mukaisesti sovittaessaan heidän teoriaansa suomalaiseen aineistoonsa.

Tutkimuksen kärkeen on nostettu deleuzelainen käsite kirjoittava kone, jonka kautta Untolan tuotantoa ja kirjallista toimintaa kuvataan alati toimivan koneen erilaisina tuotoksina, komponentteina, jotka kytkeytyvät eri tavoin toisiinsa. Tällaisenaan Deleuzen ja Quattarin tekijäkäsitys toden totta "irtaantuu tekijätutkimukseen helposti sulahtavasta subjektivismista ja yksilökeskeisyydestä" (s. 27), jopa niin vahvasti, että minulle tehdaskuvasto tuo mieleen kapitalismin historian ja nykypäivänkin hikipajat, joissa yksilö tuhoutuu taloudellisen voiton vuoksi. Oppiisiensä tarjoaman mallin lisäksi Kurikka motivoi kone-käsitteen käyttöä Untola-tutkimuksessa tämän tuotannossa esiintyvän kone- ja tehdaskuvaston kautta, joka kytkeytyy tuon ajan yleisempään näkemykseen moderniteetista.

Untolan toimiin konemaisuus ja kylmyys kyllä sopii, esimerkiksi hänen tapaansa kommunikoida pelkästään kirjallisesti kustantajansa kanssa. Tätä Kurikka analysoi osana Untolan kieltäytymistä kasvoistumisesta, jossa Untola meni niin pitkälle, ettei suostunut ottamaan vastaan edes rahapalkintoja työstään vaikka toisaalta esitti kirjoittamisensa olevan puhdasta työtä, leivän hankkimista. Tässä yksi ristiriidoista, joita Untolan tekijäkuviin sisältyi. Kirjallisuushistoriallisesti kiintoisaa on, että kasvoistumisesta kieltäytyminen liittyi osaltaan Untolan ärsyyntymiseen tuon ajan kaupallisuuden mekanismeihin, jotka Kurikan tutkimus osoittaa samankaltaisiksi kuin nykyiset. 
Yhden vahvan ja vähän Suomessa sovelletun metodin asettaminen tutkimuksen rungoksi tekee tutkimuksesta koherentin ja teoriataustaltaan tuoreen. Väitöskirja on rohkea ja luova, mikä näkyy myös Kurikan kirjoitustyylissä. Kääntöpuolena yhden vahvan ja omaleimaisen teorian soveltamisessa on se, että monimutkainen kehikko uhkaa hukuttaa alleen itse asian eli Untolan moninimisen tekijyyden avaamisen. Tutkimus lähtee liikkeelle odotetusta lupauksesta uudistaa Barthesin ja Foucault'n teesien jäljillä yhäkin roikkuvaa tekijätutkimusta, mutta metodin haastavuus ei rohkaise sen soveltamiseen. Välillä pohdin, auttaako käytetty teoria minua ymmärtämään Untolan tekijyyden elementtejä vai tekeekö se ymmärtämisestä vain hankalampaa.

Untolan tekijäpolitiikan äärimmäinen kompleksisuus tulee havainnollistavasti esiin väitöskirjassa. Teos aiheuttaa varsinaisen tornadon jatkoajatuksia ja uusia ideoita, sillä niin Deleuzen ja Guattarin kuin Kurikankin muotoilut antavat tilaa lukijan omille tulkinnoille. Kysymyksiä tulee mieleen sen verran paljon, että tilausta olisi vaikka kansainväliseen tyyliin haastatteluartikkelille, jossa tutkija oikoisi hätäisten ja sivistymättömien lukijoidensa väärinkäsityksiä.

Algot Untolan tekijyyksien tuotannolle tutkimus tekee kunniaa. Väitös myös muistuttaa, miten kutkuttavia kirjailijoita suomalaisesta kirjallisuudesta löytyy. Toivottavasti Untola-tutkimus saa jatkoa, ellei Kurikan niin jonkun muun toimesta. Suurtuotannossa riittää pengottavaa.

\section{Kirjoittaja}

Päivi Koivisto, FT, Helsingin yliopisto, kotimainen kirjallisuus

(pakoivis[at]gmail.com)

\section{Kiven kirjeet hyvin toimitettuina}

Aleksis Kivi: Kirjeet. Kriittinen editio. Toimittaneet Juhani Niemi (päätoimittaja), Sakari Katajamäki, Ossi Kokko, Petri Lauerma, Jyrki Nummi. Ruotsinkieliset kirjeet suomentanut Juhani Lindholm. Suomalaisen Kirjallisuuden Seuran toimituksia I386. Helsinki: SKS, 2013. 426 s.

Kirjeet ovat Aleksis Kiven puutteellisesti tunnettujen elämänvaiheiden paras lähde. Melkein kaikki muu aineisto on kuulopuhetta ja muistitietoa, joka on kerätty talteen vasta Kiven kuoleman jälkeen. Sen pätevyyttä on ollut ja on vaikea arvioida. Kirjeiden kriittinen editio on korvaama- 